University of Wollongong

Research Online

Faculty of Social Sciences - Papers (Archive) Faculty of Arts, Social Sciences \& Humanities

2008

Positive association between plasma homocysteine level and chronic kidney disease

Anoop Shankar

National University of Singapore

Jie Wang

University of Sydney

Brian Chua

University of Sydney

Elena Rochtchina

University of Sydney

Victoria Flood

University of Wollongong, vflood@uow.edu.au

See next page for additional authors

Follow this and additional works at: https://ro.uow.edu.au/sspapers

Part of the Education Commons, and the Social and Behavioral Sciences Commons

Research Online is the open access institutional repository for the University of Wollongong. For further information contact the UOW Library: research-pubs@uow.edu.au 


\title{
Positive association between plasma homocysteine level and chronic kidney disease
}

\begin{abstract}
BACKGROUND:

Increasing experimental evidence, including recently developed animal models, supports a role for homocysteine in the development of chronic kidney disease (CKD). However, relatively few clinical/ epidemiological studies have examined this hypothesis in humans. We examined the relationship between plasma homocysteine level and CKD in a population-based study of older Australians.
\end{abstract}

\section{METHODS:}

Community-based study (1992-1994) among 2,609 individuals (58.6\% women), aged 49-98 years, free of clinical cardiovascular disease in the Blue Mountains region, west of Sydney, Australia. The main outcome-of-interest was CKD $(n=461)$, defined as estimated glomerular filtration rate of $<60 \mathrm{ml}>/ \mathrm{min} /$ $1.73 \mathrm{~m}(2)$.

\section{RESULTS:}

Higher plasma homocysteine levels were positively associated with CKD, independent of smoking, body mass index, diabetes mellitus, hypertension, cholesterol levels, and other confounders. The multivariable odds ratio (OR; $95 \%$ confidence intervals, $\mathrm{Cl}$ ) comparing quartile 4 of plasma homocysteine (>14 micromol/l) to quartile 1 ( $<$ or $=9 \mathrm{micromol} / \mathrm{l})$ was $10.44(6.99-15.60)$, p-trend $<0.0001$. This association persisted in both men and women separately. The results were also consistent in subgroup analyses by categories of diabetes mellitus and hypertension.

\section{CONCLUSIONS:}

Higher plasma homocysteine levels are associated with CKD in a community-based sample of older Australians. This association appeared to be independent of diabetes mellitus and hypertension.

\section{Keywords}

between, plasma, homocysteine, level, chronic, association, positive, disease, kidney

\section{Disciplines}

Education | Social and Behavioral Sciences

\section{Publication Details}

Shankar, A., Wang, J. Jin., Chua, B., Rochtchina, E., Flood, V. \& Mitchell, P. (2008). Positive association between plasma homocysteine level and chronic kidney disease. Kidney and Blood Pressure Research, 31 (1), 55-62.

\section{Authors}

Anoop Shankar, Jie Wang, Brian Chua, Elena Rochtchina, Victoria Flood, and Paul Mitchell 


\title{
Positive Association between Plasma Homocysteine Level and Chronic Kidney Disease
}

\author{
Anoop Shankar ${ }^{\mathrm{a}}$ Jie Jin Wang ${ }^{\mathrm{b}}$ Brian Chua $^{\mathrm{b}}$ Elena Rochtchina ${ }^{\mathrm{b}}$ Vicki Flood $^{\mathrm{b}, \mathrm{c}}$ \\ Paul Mitchell ${ }^{b}$ \\ aDivision of Epidemiology, Department of Community, Occupational, and Family Medicine, \\ National University of Singapore, Singapore; ${ }^{b}$ Centre for Vision Research, Department of Ophthalmology and \\ Westmead Millennium Institute, and 'Human Nutrition Unit, Departments of Molecular and \\ Microbial Biosciences and School of Public Health, University of Sydney, Sydney, N.S.W., Australia
}

\section{Key Words \\ Plasma homocysteine $\cdot$ Chronic kidney disease $\cdot$ \\ Hypertension • Blue Mountains Eye Study}

\section{Abstract}

Background: Increasing experimental evidence, including recently developed animal models, supports a role for homocysteine in the development of chronic kidney disease (CKD). However, relatively few clinical/epidemiological studies have examined this hypothesis in humans. We examined the relationship between plasma homocysteine level and CKD in a population-based study of older Australians. Methods: Community-based study (1992-1994) among 2,609 individuals (58.6\% women), aged 49-98 years, free of clinical cardiovascular disease in the Blue Mountains region, west of Sydney, Australia. The main outcome-of-interest was CKD $(n=461)$, defined as estimated glomerular filtration rate of $<60 \mathrm{ml} / \mathrm{min} / 1.73 \mathrm{~m}^{2}$. Results: Higher plasma homocysteine levels were positively associated with CKD, independent of smoking, body mass index, diabetes mellitus, hypertension, cholesterol levels, and other confounders. The multivariable odds ratio (OR; $95 \%$ confidence intervals, $\mathrm{Cl}$ ) comparing quartile 4 of plasma homocysteine ( $>14 \mu \mathrm{mol} / \mathrm{l})$ to quartile 1 ( $\leq 9 \mu \mathrm{mol} / \mathrm{l})$ was 10.44 (6.99-15.60), p-trend $<0.0001$. This association persisted in both men and women separately. The results were also consistent in subgroup analyses by categories of diabetes mellitus and hypertension. Conclusions: Higher plasma homocysteine levels are associated with CKD in a community-based sample of older Australians. This association appeared to be independent of diabetes mellitus and hypertension.

Copyright $\odot 2008$ S. Karger AG, Basel

\section{Introduction}

End-stage renal disease (ESRD) is an important public health problem. There were estimated to be approximately 470,000 patients with ESRD in the United States in 2004 [1], and based on earlier data an estimated additional 8 million US adults have chronic kidney disease (CKD), defined as a glomerular filtration rate (GFR) of $<60 \mathrm{ml} /$ $\mathrm{min} / 1.73 \mathrm{~m}^{2}$, who are at risk of progression to ESRD and its attendant complications $[2,3]$. It is therefore important to identify factors related to CKD, a kidney disease stage earlier in the continuum at which prevention/control of disease progression is more applicable.

Supported principally by the Australian National Health and Medical Research Council, Canberra, Australia (Project grant ID 974159 and 211069), and in part by the Kellogg's Foundation, Australia.

\section{KARGER \\ Fax +41613061234 \\ E-Mail karger@karger.ch}

www.karger.com

\author{
2008 S. Karger AG, Basel \\ $1420-4096 / 08 / 0311-0055 \$ 24.50 / 0$ \\ Accessible online at: \\ www.karger.com/kbr
}

\footnotetext{
Dr. Anoop Shankar

Department of Community, Occupational, and Family Medicine

National University of Singapore

Singapore 117597 (Singapore)

Tel. +65 6874 4968, Fax +65 6779 1489, E-Mail ashankar@nus.edu.sg
} 
Homocysteine is a sulfur-containing amino acid formed during the metabolism of the essential amino acid methionine [4]. Previous epidemiologic studies have reported an association between plasma homocysteine levels and atherosclerotic vascular disease [4-6], shown to be a predictor of subsequent CKD [7]. Studies have also reported an association between plasma homocysteine and hypertension $[8,9]$, another strong, independent predictor of CKD [10]. Homocysteine may directly cause renal vascular damage through the production of reactive oxygen species, effects on vascular smooth muscle cells, endothelial injury, reduction in plasma and tissue interstitium adenosine levels, and mesangial cell proliferation and apoptosis [4, 11-16]. Experimental animal models of homocysteine-induced glomerular damage have also been developed $[14,17]$. However, few studies have examined the putative association between elevated plasma homocysteine and CKD [18-20]. While one large study reported a positive association between homocysteine and CKD in a Japanese population sample [18], two earlier studies did not find an independent association [19, 20]. In particular, it is not clear if plasma homocysteine is related to CKD independent of hypertension and diabetes mellitus, two of its strong predictors. In this context, we examined the association between plasma homocysteine levels and CKD in a population-based sample of older Australian adults after adjusting for the major confounders and stratifying by hypertension and diabetes mellitus status.

\section{Methods}

The current report is based on the second Blue Mountains Eye Study (BMES II, 1997-2000), a population-based study of participants aged $\geq 49$ years, living in two postcodes of the Blue Mountains region, west of Sydney, Australia, which has studied age-related eye diseases and other health outcomes in an older urban Australian population. Details of the study methods have previously been described [21]. In brief, this cross-sectional survey (BMES II, 1997-2000) consisted of 3,509 participants. It included 2,335 participants (75.1\% survivors from the baseline survey, BMES I, 1992-1994) plus an additional 1,174 participants (identified in a repeat door-to-door census, 1999-2000) who had become eligible by moving into the area or into the age bracket of the original survey. The Blue Mountains population is representative of the Australian population. This study followed the recommendations of the Declaration of Helsinki, was approved by the Western Sydney Area Health Service Human Research Ethics Committee, and written, informed consent was obtained from all participants.

The examination protocols involved measurement of weight, height, systolic and diastolic blood pressures by a trained interviewer, and administration of a standardized questionnaire col- lecting information regarding demographic characteristics, cigarette smoking, alcohol intake, physical activity, and past medical history.

Fasting blood specimens were drawn from 2,961 participants (84.4\%), centrifuged onsite and then couriered the same day to Westmead Hospital, Sydney, Australia, for hematology and clinical biochemistry assessment. Plasma total homocysteine was determined using the fluorescent polarization immunoassay method on an IMx Analyzer. This system correlates well with HPLC and gas chromatography-mass spectrometry assay methods [22]. Serum folate and vitamin $B_{12}$ assays were performed using the competitive-binding assay method on a Beckman-Access analyzer. White blood cell (WBC) count was determined using a Coulter counter method. Total cholesterol, high-density lipoprotein cholesterol and triglyceride were measured on a Reflotron reflectance photometric analyzer (Boehringer Mannheim Diagnostics [currently Roche Diagnostics], Germany). Fasting plasma glucose was measured using the hexokinase method.

Age was defined as age at the baseline examination; education was categorized into beyond high school, high school, and below high school, and body mass index (BMI) was calculated as weight $(\mathrm{kg})$ divided by height squared $\left(\mathrm{m}^{2}\right)$. Diabetes status was categorized using the American Diabetes Association criteria as follows: diabetes = diagnosis by a physician and use of diabetic medications or fasting glucose levels at least $7.0 \mathrm{mmol} / \mathrm{l}(126 \mathrm{mg} / \mathrm{dl})$; fasting hyperglycemia = fasting glucose levels $6.1 \mathrm{mmol} / 1(110 \mathrm{mg} / \mathrm{dl})$ or above but less than $7.0 \mathrm{mmol} / \mathrm{l}(126 \mathrm{mg} / \mathrm{dl})$, and normoglyce$\mathrm{mia}$ = fasting glucose levels below $6.1 \mathrm{mmol} / \mathrm{l}(110 \mathrm{mg} / \mathrm{dl})$. Cigarette smoking was categorized into current (current smoker or had stopped smoking $<12$ months before the study examination), former (positively answered to 'have you ever smoked regularly before?' and had stopped smoking at least 12 months before the study examination), and never smoker. Alcohol intake was categorized as nondrinker, <once/week, 1-6 days/week, 1-2 drinks/day, 3 or more drinks/day, and don't know/missing. Physical inactivity (yes, no) was categorized as answering negatively to 'have you participated in any recreational exercise/walk in the last 2 weeks?'.

Details of blood pressure measurement and prevalence of hypertension in this older Australian community have been described previously [23]. Briefly, systolic and diastolic blood pressure was recorded by trained observers from the right arm with a mercury sphygmomanometer using a cuff size appropriate for the participant's arm circumference, after they had been comfortably seated for at least $10 \mathrm{~min}$. Hypertension was defined according to the Seventh Report of the Joint National Committee on Prevention, Detection, Evaluation, and Treatment of High Blood Pressure as a systolic blood pressure of $140 \mathrm{~mm} \mathrm{Hg}$ or higher, diastolic blood pressure $90 \mathrm{~mm} \mathrm{Hg}$ or higher, or a combination of selfreported hypertension diagnosis and use of antihypertensive medications [24].

Estimated GFR (eGFR) was the preferred measure of kidney function in the current study. GFR was indirectly estimated using the 4-variable Modification of Diet in Renal Disease Study equation [25]. The main outcome of interest was CKD, defined as an eGFR of $<60 \mathrm{ml} / \mathrm{min} / 1.73 \mathrm{~m}^{2}$, consistent with the National Kidney Foundation Kidney Disease Outcomes Quality Initiative $\geq$ stage 2 chronic kidney disease [2].

To examine the association between plasma homocysteine and hypertension and CKD of the 2,961 individuals who participated in the survey and had plasma homocysteine measured, the 
Table 1. Baseline characteristics of the cohort by quartiles of plasma homocysteine

\begin{tabular}{|c|c|c|c|c|c|}
\hline \multirow[t]{3}{*}{ Characteristics } & \multicolumn{4}{|c|}{ Quartile of plasma homocysteine $(\mu \mathrm{mol} / \mathrm{l})$} & \multirow[t]{3}{*}{$\mathrm{p}$ value } \\
\hline & quartile 1 & quartile 2 & quartile 3 & quartile 4 & \\
\hline & $\leq 9.9 \mu \mathrm{mol} / \mathrm{l}$ & $10.0-11.9 \mu \mathrm{mol} / \mathrm{l}$ & $12.0-14.9 \mu \mathrm{mol} / \mathrm{l}$ & $>14.9 \mu \mathrm{mol} / \mathrm{l}$ & \\
\hline Age, years & $62.2 \pm 0.3$ & $65.3 \pm 0.3$ & $67.5 \pm 0.4$ & $70.9 \pm 0.3$ & $<0.0001$ \\
\hline Women, \% & 73.5 & 56.4 & 52.6 & 47.1 & $<0.0001$ \\
\hline \multicolumn{6}{|l|}{ Smoking } \\
\hline Current smoker, $\%$ & 9.4 & 9.0 & 9.7 & 9.7 & 0.97 \\
\hline Former smoker, \% & 35.7 & 38.3 & 40.2 & 46.7 & 0.0003 \\
\hline Alcohol use $>3$ drinks/day, $\%$ & 11.8 & 15.7 & 16.2 & 18.9 & 0.003 \\
\hline Body mass index, $\mathrm{kg} / \mathrm{m}^{2}$ & $27.2 \pm 0.2$ & $27.3 \pm 0.2$ & $27.9 \pm 0.2$ & $28.0 \pm 0.2$ & 0.001 \\
\hline Physically inactive, $\%$ & 16.0 & 20.4 & 24.0 & 29.0 & $<0.0001$ \\
\hline Diabetes mellitus, $\%$ & 9.0 & 9.7 & 10.3 & 10.6 & 0.08 \\
\hline Serum total cholesterol, $\mathrm{mmol} / \mathrm{l}$ & $5.8 \pm 0.04$ & $5.8 \pm 0.04$ & $5.9 \pm 0.04$ & $5.9 \pm 0.04$ & 0.04 \\
\hline Serum triglyceride, $\mathrm{mmol} / \mathrm{l}$ & $1.53 \pm 0.03$ & $1.53 \pm 0.04$ & $1.55 \pm 0.04$ & $1.59 \pm 0.04$ & 0.04 \\
\hline Serum HDL cholesterol, $\mathrm{mmol} / \mathrm{l}$ & $1.53 \pm 0.01$ & $1.46 \pm 0.02$ & $1.47 \pm 0.02$ & $1.45 \pm 0.02$ & 0.0006 \\
\hline Mean arterial pressure, $\mathrm{mm} \mathrm{Hg}$ & $104.2 \pm 1.1$ & $106.8 \pm 1.2$ & $106.5 \pm 1.4$ & $108.2 \pm 1.2$ & 0.03 \\
\hline Hypertension, \% & 68.2 & 77.2 & 79.7 & 82.0 & $<0.0001$ \\
\hline $\mathrm{eGFR}, \mathrm{ml} / \mathrm{min} / 1.73 \mathrm{~m}^{2}$ & $81.7 \pm 0.6$ & $75.9 \pm 0.7$ & $71.5 \pm 0.8$ & $65.0 \pm 0.7$ & $<0.0001$ \\
\hline Chronic kidney disease (\%) & 4.7 & 11.7 & 20.5 & 37.2 & $<0.0001$ \\
\hline \multicolumn{6}{|l|}{ Women only } \\
\hline Menopausal status, \% & 93.5 & 95.9 & 97.3 & 98.4 & 0.003 \\
\hline Hormone replacement therapy,\% & 45.3 & 41.8 & 30.5 & 25.6 & $<0.0001$ \\
\hline
\end{tabular}

The data presented are mean \pm SD values or row percentages. The p values are based on analysis of variance or the $\chi^{2}$ test, as appropriate. $\mathrm{eGFR}=$ Estimated glomerular filtration rate based on the Modification of Diet in Renal Diseases study equation [25].

current study included 2,609 individuals free of clinical cardiovascular disease (1,080 men and 1,529 women) after excluding those with missing systolic or diastolic blood pressure $(n=23)$, serum creatinine levels $(\mathrm{n}=10)$, and those with preexisting coronary heart disease $(n=223)$ or stroke $(n=96)$.

\section{Statistical Methods}

Baseline plasma homocysteine was categorized into quartiles $(\leq 9.9,10.0-11.9,12.0-14.9,>14.9 \mu \mathrm{mol} / \mathrm{l})$ for the main analyses. Homocysteine was also analyzed as a continuous variable (1 SD $[4.6 \mu \mathrm{mol} / \mathrm{l}]$ increase). We used $\chi^{2}$ test and analysis of variance to compare the relationship of selected baseline characteristics by plasma homocysteine quartiles. We were interested in two outcomes (1) hypertension and (2) CKD. We used multivariable logistic regression models to determine the odds ratio $(\mathrm{OR})$ and $95 \%$ confidence interval $(\mathrm{CI})$ of hypertension $(\mathrm{n}=1,986)$ and CKD ( $\mathrm{n}=461)$, controlling for potential confounders. We used 2 logistic regression models: an age- (years), sex-adjusted model, and a multivariable-adjusted model, additionally adjusting for smoking (never, former, current), alcohol intake (nondrinker, $<3$ drinks/day, $\geq 3$ drinks/day), BMI $\left(\mathrm{kg} / \mathrm{m}^{2}\right)$, physically inactive (no, yes), diabetes mellitus (absent, present), hypertension (absent, present; adjusted in models with CKD as the outcome), mean arterial blood pressure ( $\mathrm{mm} \mathrm{Hg}$; adjusted in models with CKD as the outcome), serum total cholesterol ( $\mathrm{mmol} / \mathrm{l})$, HDL cholesterol ( $\mathrm{mmol} / \mathrm{l})$, triglyceride $(\mathrm{mmol} / \mathrm{l})$; among women we additionally adjusted for menopausal status (absent, present), and ever use of hormone replacement therapy (no, yes). Logistic regression mod- els with plasma homocysteine quartiles as ordered categories scaled to the median for each quartile were used to assess trends in OR. To examine the consistency of the association between homocysteine and CKD, we performed analyses within subgroups of major confounders, including gender (men, women), hypertension (absent, present), and diabetes mellitus (absent, present). We formally evaluated effect modification by including cross-product interaction terms in corresponding logistic regression models. We also performed several supplementary analyses. First, we repeated the multivariable model additionally adjusting for serum folate and vitamin $B_{12}$ to examine if the observed association between plasma homocysteine and CKD was explained by these micronutrients. Second, to examine if the observed association between plasma homocysteine and CKD was explained by inflammation, we repeated the multivariable model additionally adjusting for WBC count, a nonspecific marker of inflammation available in the current study. SAS version 9.2 was used for all analyses.

\section{Results}

Among the 2,609 adults aged $\geq 49$ years without clinical cardiovascular disease who were included in the current analysis, 1,986 subjects had hypertension and 461 had CKD. Table 1 presents the characteristics of the study population by plasma homocysteine quartiles. Subjects 
Table 2. Association between quartiles of plasma homocysteine and hypertension

\begin{tabular}{|c|c|c|c|c|}
\hline Plasma homocysteine quartiles & $\begin{array}{l}\text { Number } \\
\text { at risk }\end{array}$ & $\begin{array}{l}\text { Hypertension } \\
\text { cases }\end{array}$ & $\begin{array}{l}\text { Age, sex } \\
\text { OR }(95 \% \mathrm{CI})\end{array}$ & $\begin{array}{l}\text { Multivariable OR } \\
(95 \% \mathrm{CI})^{\mathrm{a}}\end{array}$ \\
\hline \multicolumn{5}{|l|}{ Whole cohort $(n=2,609)$} \\
\hline Quartile $1(\leq 9.9 \mu \mathrm{mol} / \mathrm{l})$ & 802 & 547 & 1 (referent) & 1 (referent) \\
\hline Quartile $2(10.0-11.9 \mu \mathrm{mol} / \mathrm{l})$ & 658 & 508 & $1.41(1.11-1.80)$ & $1.26(0.98-1.63)$ \\
\hline Quartile $3(12.0-14.9 \mu \mathrm{mol} / \mathrm{l})$ & 487 & 388 & $1.46(1.11-1.94)$ & $1.30(0.97-1.74)$ \\
\hline Quartile $4(>14.9 \mu \mathrm{mol} / \mathrm{l})$ & 662 & 543 & $1.48(1.12-1.96)$ & $1.41(1.06-1.88)$ \\
\hline p-trend & & & 0.0034 & 0.0178 \\
\hline One SD $(4.6 \mu \mathrm{mol} / \mathrm{l})$ increase & 2,609 & 1,986 & $1.29(1.19-1.40)$ & $1.23(1.14-1.32)$ \\
\hline
\end{tabular}

Table 3. Association between quartiles of plasma homocysteine and chronic kidney disease (CKD)

\begin{tabular}{|c|c|c|c|c|}
\hline Plasma homocysteine quartiles & $\begin{array}{l}\text { Number } \\
\text { at risk }\end{array}$ & CKD cases & $\begin{array}{l}\text { Age, sex } \\
\text { OR }(95 \% \text { CI })\end{array}$ & $\begin{array}{l}\text { Multivariable OR } \\
(95 \% \text { CI })^{\mathrm{a}}\end{array}$ \\
\hline \multicolumn{5}{|l|}{ Whole cohort $(\mathrm{n}=2,609)$} \\
\hline Quartile $1(\leq 9.9 \mu \mathrm{mol} / \mathrm{l})$ & 802 & 38 & 1 (referent) & 1 (referent) \\
\hline Quartile $2(10.0-11.9 \mu \mathrm{mol} / \mathrm{l})$ & 658 & 77 & $2.67(1.78-3.99)$ & $2.54(1.66-3.89)$ \\
\hline Quartile $3(12.0-14.9 \mu \mathrm{mol} / \mathrm{l})$ & 487 & 100 & $5.20(3.51-7.70)$ & $4.68(3.07-7.13)$ \\
\hline Quartile $4(>14.9 \mu \mathrm{mol} / \mathrm{l})$ & 662 & 246 & $11.89(8.28-17.07)$ & $10.44(6.99-15.60)$ \\
\hline p-trend & & & $<0.0001$ & $<0.0001$ \\
\hline One SD $(4.6 \mu \mathrm{mol} / \mathrm{l})$ increase & 2,609 & 461 & $2.24(2.00-2.51)$ & $2.12(1.89-2.39)$ \\
\hline
\end{tabular}

OR = Odds ratio; $95 \% \mathrm{CI}=95 \%$ confidence interval.

${ }^{a}$ Estimated from a logistic regression model adjusted for age (years), sex, smoking (never, former, current), alcohol intake (nondrinker, $<3$ drinks/day, $\geq 3$ drinks/day), body mass index (kg/ $\mathrm{m}^{2}$ ), physically inactive (no, yes), diabetes mellitus (absent, pres- ent), hypertension (absent, present), mean arterial blood pressure $(\mathrm{mm} \mathrm{Hg})$, serum total cholesterol ( $\mathrm{mmol} / \mathrm{l}), \mathrm{HDL}$ cholesterol $(\mathrm{mmol} / \mathrm{l})$, triglyceride $(\mathrm{mmol} / \mathrm{l})$. Among women we additionally adjusted for menopausal status (absent, present), and ever use of hormone replacement therapy (yes, no). with higher plasma homocysteine levels were more likely to be older, former smokers, physically inactive, diabetic, hypertensive, to have consumed $>3$ drinks of alcohol/day, higher BMI, higher serum total cholesterol and triglyceride levels, lower HDL cholesterol levels, and higher mean arterial pressure, and were less likely to be women than those with lower plasma homocysteine. The mean eGFR decreased and the prevalence of CKD increased with increasing plasma homocysteine quartiles.

In table 2, increasing plasma homocysteine quartiles were positively associated with hypertension in both the age- and sex-adjusted and multivariable-adjusted mod- els; models evaluating trend in this association were also statistically significant. When plasma homocysteine was analyzed as a continuous variable (per SD increase) the positive association with hypertension persisted. Also in a related subsidiary analysis (data not shown in tables), we confirmed that hypertension was positively associated with CKD in the current study sample (multivariable OR $1.98,95 \%$ CI 1.12-3.50).

Table 3 presents the OR of CKD by increasing plasma homocysteine quartiles. Increasing plasma homocysteine quartiles were strongly positively associated with CKD. When plasma homocysteine was analyzed as a con- 
Table 4. Association between quartiles of plasma homocysteine and chronic kidney disease $(\mathrm{CKD})$ by gender

\begin{tabular}{llll}
\hline Plasma homocysteine quartiles & $\begin{array}{l}\text { Number } \\
\text { at risk }\end{array}$ & CKD cases & $\begin{array}{l}\text { Multivariable OR } \\
(95 \% \mathrm{CI})^{\mathrm{a}}\end{array}$ \\
\hline Men $(\mathrm{n}=1,080)$ & & & \\
Quartile 1 $(\leq 9.9 \mu \mathrm{mol} / \mathrm{l})$ & 212 & 4 & 1 (referent) \\
Quartile 2 $(10.0-11.9 \mu \mathrm{mol} / \mathrm{l})$ & 287 & 9 & $1.22(0.36-4.19)$ \\
Quartile 3 $(12.0-14.9 \mu \mathrm{mol} / \mathrm{l})$ & 231 & 16 & $2.82(0.90-8.95)$ \\
Quartile 4 $(>14.9 \mu \mathrm{mol} / \mathrm{l})$ & 350 & 83 & $8.85(3.05-25.70)$ \\
p-trend & & & $<0.0001$ \\
Women $(\mathrm{n}=1,529)$ & 590 & 34 & $1($ referent $)$ \\
Quartile 1 $(\leq 9.9 \mu \mathrm{mol} / \mathrm{l})$ & 371 & 68 & $2.85(1.81-4.49)$ \\
Quartile 2 $(10.0-11.9 \mu \mathrm{mol} / \mathrm{l})$ & 256 & 84 & $5.29(3.35-8.35)$ \\
Quartile 3 $(12.0-14.9 \mu \mathrm{mol} / \mathrm{l})$ & 312 & 163 & $11.12(6.45-19.17)$ \\
Quartile 4 $(>14.9 \mu \mathrm{mol} / \mathrm{l})$ & & & $<0.0001$ \\
p-trend & & &
\end{tabular}

OR $=$ Odds ratio $; 95 \% \mathrm{CI}=95 \%$ confidence interval.

a Estimated from a logistic regression model adjusted for age (years), sex, smoking (never, former, current), alcohol intake (nondrinker, $<3$ drinks/day, $\geq 3$ drinks/day), body mass index $\left(\mathrm{kg} / \mathrm{m}^{2}\right)$, physically inactive (no, yes), diabetes mellitus (absent, present), hypertension (absent, present), mean arterial blood pressure ( $\mathrm{mm} \mathrm{Hg}$ ), serum total cholesterol (mmol/l), HDL cholesterol ( $\mathrm{mmol} / \mathrm{l})$, triglyceride ( $\mathrm{mmol} / \mathrm{l})$. Among women we additionally adjusted for menopausal status (absent, present), and ever use of hormone replacement therapy (yes, no). tinuous variable the positive association with CKD persisted.

Table 4 shows a clear positive association between plasma homocysteine levels and CKD in both men and women. Similarly, a consistent positive association was observed in subgroup analyses after stratifying by the presence of hypertension (table 5) or diabetes mellitus (table 6).

We also performed several supplementary analyses. First, we repeated the main analysis additionally adjusting for serum folate and vitamin $B_{12}$ in the multivariable model; the observed association between plasma homocysteine quartiles and CKD remained largely unchanged. Compared to quartile 1 of plasma homocysteine, the multivariable OR of CKD was 2.87 (95\% CI 1.86-4.43) in quartile 2 ; 5.62 (3.63-8.71) in quartile 3 , and 13.72 (8.9121.13 ) in quartile 4 (p-trend $<0.0001)$. Second, to examine if the observed association between plasma homocysteine and CKD was explained by inflammation, we repeated the multivariable model additionally adjusting for WBC count; results remained similar here also. Compared to quartile 1 of plasma homocysteine, the multivariable OR of CKD was 2.53 (95\% CI 1.65-3.88) in quartile $2 ; 4.65$ (3.05-7.09) in quartile 3 , and $10.36(6.93-15.47)$ in quartile 4 (p-trend $<0.0001)$.

\section{Discussion}

Higher plasma homocysteine levels were found to be positively associated with CKD in a population-based sample of older Australians, free of clinical cardiovascular disease. This association persisted after adjusting for age, sex, BMI, smoking, alcohol intake, diabetes mellitus and hypertension, and was consistently present in subgroup analysis by gender and important confounders. The OR for the likely presence of CKD increased in a dose-dependent manner with increasing quartiles of plasma homocysteine. Our results contribute to the literature by suggesting that the putative plasma homocysteine-CKD association appears to be independent of both diabetes mellitus and hypertension.

Our finding of a positive association between higher plasma homocysteine levels and CKD shows high internal validity as shown by the magnitude of this association, its independence from related factors such as smoking, alcohol intake, BMI, diabetes mellitus, hypertension, and serum lipid levels, the presence of a dose-response trend, and the consistency of this association in subgroup analyses by gender, and other important confounders. Also, several lines of recent evidence suggest that an association between plasma homocysteine and renal vascular damage and subsequent CKD is plausible, including a

Kidney Blood Press Res 2008;31:55-62 
Table 5. Association between quartiles of plasma homocysteine and chronic kidney disease (CKD) by hypertension status
Table 6. Association between quartiles of plasma homocysteine and chronic kidney disease $(\mathrm{CKD})$ by diabetes status

\begin{tabular}{llll}
\hline Plasma homocysteine quartiles & $\begin{array}{l}\text { Number } \\
\text { at risk }\end{array}$ & CKD cases & $\begin{array}{l}\text { Multivariable OR } \\
(95 \% \mathrm{CI})^{\mathrm{a}}\end{array}$ \\
\hline Normotensives $(\mathrm{n}=623)$ & & & \\
Quartile 1 $(\leq 9.9 \mu \mathrm{mol} / \mathrm{l})$ & 255 & 4 & 1 (referent) \\
Quartile 2 $(10.0-11.9 \mu \mathrm{mol} / \mathrm{l})$ & 150 & 13 & $5.91(1.79-19.51)$ \\
Quartile 3 $(12.0-14.9 \mu \mathrm{mol} / \mathrm{l})$ & 99 & 18 & $15.63(4.71-51.85)$ \\
Quartile 4 $(>14.9 \mu \mathrm{mol} / \mathrm{l})$ & 119 & 34 & $23.16(7.26-73.90)$ \\
p-trend & & & $<0.0001$ \\
Hypertensives $(\mathrm{n}=1,986)$ & 547 & 34 & $1($ referent $)$ \\
Quartile 1 $(\leq 9.9 \mu \mathrm{mol} / \mathrm{l})$ & 508 & 64 & $2.17(1.37-3.44)$ \\
Quartile 2 $(10.0-11.9 \mu \mathrm{mol} / \mathrm{l})$ & 388 & 82 & $3.76(2.38-5.92)$ \\
Quartile 3 $(12.0-14.9 \mu \mathrm{mol} / \mathrm{l})$ & 543 & 212 & $9.07(5.89-13.96)$ \\
Quartile 4 $(>14.9 \mu \mathrm{mol} / \mathrm{l})$ & & & $<0.0001$ \\
p-trend & & &
\end{tabular}

OR = Odds ratio $; 95 \% \mathrm{CI}=95 \%$ confidence interval.

${ }^{a}$ Estimated from a logistic regression model adjusted for age (years), sex, smoking (never, former, current), alcohol intake (nondrinker, $<3$ drinks/day, $\geq 3$ drinks/day), body mass index $\left(\mathrm{kg} / \mathrm{m}^{2}\right)$, physically inactive (no, yes), diabetes mellitus (absent, present), hypertension (absent, present), mean arterial blood pressure ( $\mathrm{mm} \mathrm{Hg}$ ), serum total cholesterol $(\mathrm{mmol} / \mathrm{l})$, HDL cholesterol $(\mathrm{mmol} / \mathrm{l})$, triglyceride ( $\mathrm{mmol} / \mathrm{l})$. Among women we additionally adjusted for menopausal status (absent, present), and ever use of hormone replacement therapy (yes, no). p-interaction for the cross-product interaction term between hypertension $\times$ homocysteine quartiles $=0.56$.

\begin{tabular}{llcl}
\hline Plasma homocysteine quartiles & $\begin{array}{l}\text { Number } \\
\text { at risk }\end{array}$ & CKD cases & $\begin{array}{l}\text { Multivariable OR } \\
(95 \% \mathrm{CI})^{\mathrm{a}}\end{array}$ \\
\hline Subjects without diabetes mellitus $(\mathrm{n}=2,353)$ & & \\
Quartile 1 $(\leq 9.9 \mu \mathrm{mol} / \mathrm{l})$ & 730 & 34 & 1 (referent) \\
Quartile 2 $(10.0-11.9 \mu \mathrm{mol} / \mathrm{l})$ & 594 & 67 & $2.54(1.62-3.99)$ \\
Quartile 3 $(12.0-14.9 \mu \mathrm{mol} / \mathrm{l})$ & 437 & 87 & $4.62(2.96-7.21)$ \\
Quartile 4 $(>14.9 \mu \mathrm{mol} / \mathrm{l})$ & 592 & 209 & $9.68(6.33-14.81)$ \\
p-trend & & & $<0.0001$ \\
Subjects with diabetes mellitus $(\mathrm{n}=256)$ & & & $1($ referent $)$ \\
Quartile 1 $(\leq 9.9 \mu \mathrm{mol} / \mathrm{l})$ & 72 & 4 & $2.70(0.65-11.27)$ \\
Quartile 2 $(10.0-11.9 \mu \mathrm{mol} / \mathrm{l})$ & 64 & 10 & $5.46(1.38-21.54)$ \\
Quartile 3 $(12.0-14.9 \mu \mathrm{mol} / \mathrm{l})$ & 50 & 13 & $23.16(6.12-87.60)$ \\
Quartile 4 $(>14.9 \mu \mathrm{mol} / \mathrm{l})$ & 70 & 37 & $<0.0001$ \\
p-trend & & &
\end{tabular}

OR $=$ Odds ratio $; 95 \% \mathrm{CI}=95 \%$ confidence interval.

a Estimated from a logistic regression model adjusted for age (years), sex, smoking (never, former, current), alcohol intake (nondrinker, $<3$ drinks/day, $\geq 3$ drinks/day), body mass index $\left(\mathrm{kg} / \mathrm{m}^{2}\right)$, physically inactive (no, yes), diabetes mellitus (absent, present), hypertension (absent, present), mean arterial blood pressure ( $\mathrm{mm} \mathrm{Hg}$ ), serum total cholesterol (mmol/l), HDL cholesterol ( $\mathrm{mmol} / \mathrm{l})$, triglyceride ( $\mathrm{mmol} / \mathrm{l})$. Among women we additionally adjusted for menopausal status (absent, present), and ever use of hormone replacement therapy (yes, no). p-interaction for the cross-product interaction term between diabetes $\times$ homocysteine quartiles $=0.22$. 
role of homocysteine in the production of reactive oxygen species, effects on vascular smooth muscle cells, endothelial injury, reduction in plasma and tissue interstitium adenosine levels, and mesangial cell proliferation and apoptosis [4, 11-16]. Furthermore, experimental animal models of homocysteine-induced glomerular damage have recently been developed $[14,17]$.

However, relatively few epidemiological studies to date have examined the putative association between plasma homocysteine levels and CKD [18-20], and several important questions regarding this association need further clarification. First, while one large study reported a positive association between homocysteine and CKD [18], two earlier studies did not confirm this association among those without diabetes $[19,20]$. In the current study, the association between plasma homocysteine and CKD was present both among those with or without diabetes mellitus, suggesting an association independent of diabetes. Second, hypertension is a strong, independent predictor of CKD [10]. As plasma homocysteine is related to hypertension in the current study (table 2) as well as in previous reports $[8,9]$, confounding by hypertension/high blood pressure needs to be considered in the observed association with CKD. In the current study, the homocysteineCKD association appeared to be independent of hypertension based on results in the stratified analysis, and was present even after adjusting for mean arterial pressure in the multivariable model.

The main advantages of our study include its large sample size, stable general population sample base, avail- ability of rich covariate/confounder information, and the use of standardized protocols for exposure and outcome assessment. The main study limitation is the cross-sectional nature of the current study which precludes conclusions regarding the temporal nature of the association between plasma homocysteine and CKD. It is possible that at least part of the observed association is due to reverse causality, including plasma homocysteine elevations secondary to reduced renal clearance, and to disruptions in the normal extrarenal homocysteine metabolism involving unidentified uremic inhibitory substances [26]. Also, blood pressure levels were based on a single reading in the survey. This could have resulted in slight misclassification of hypertension status (likely to be overestimation). However, since we also adjusted for mean arterial pressure in the multivariable models, the effect of hypertension status misclassification on the homocysteine-CKD association is likely to be minimal.

In conclusion, higher plasma homocysteine levels were found to be positively associated with prevalent CKD in a population-based sample of older Australians, free of clinical cardiovascular disease. This association appeared to be independent of diabetes mellitus and hypertension. Future prospective studies are needed to clarify the temporal sequence of this association. As CKD is a predictor of cardiovascular disease and mortality [27], a corollary observation in light of our findings is that at least part of the reported association between plasma homocysteine and cardiovascular disease and mortality [4-6] may be mediated by its effect on renal dysfunction.

\section{References}

1 US Renal Data System. USRDS 2006 Annual Data Report: Atlas of End-Stage Renal Disease in the United States. Bethesda, National Institutes of Health, National Institute of Diabetes and Digestive and Kidney Diseases, 2006.

2 National Kidney Foundation: K/DOQI clinical practice guidelines for chronic kidney disease: evaluation, classification, and stratification. Am J Kidney Dis 2002;39(suppl 1): S1-S266.

3 Coresh J, Astor BC, Greene T, Eknoyan G, Levey AS: Prevalence of chronic kidney disease and decreased kidney function in the adult US population: Third National Health and Nutrition Examination Survey. Am J Kidney Dis 2003;41:1-12.

4 Welch GN, Loscalzo J: Homocysteine and atherothrombosis. N Engl J Med 1998;338: 1042-1050.
5 Nygard O, Nordrehaug JE, Refsum H, Ueland PM, Farstad M, Vollset SE: Plasma homocysteine levels and mortality in patients with coronary artery disease. N Engl J Med 1997; 337:230-236.

6 Bots ML, Launer LJ, Lindemans J, Hoes AW, Hofman A, Witteman JC, Koudstaal PJ, Grobbee DE: Homocysteine and short-term risk of myocardial infarction and stroke in the elderly: the Rotterdam Study. Arch Intern Med 1999;159:38-44.

7 Elsayed EF, Tighiouart H, Griffith J, Kurth T, Levey AS, Salem D, Sarnak MJ, Weiner DE: Cardiovascular disease and subsequent kidney disease. Arch Intern Med 2007;167: 1130-1136.

8 Lim U, Cassano PA: Homocysteine and blood pressure in the Third National Health and Nutrition Examination Survey, 19881994. Am J Epidemiol 2002;156:1105-1113.
9 Bowman TS, Gaziano JM, Stampfer MJ, Sesso HD: Homocysteine and risk of developing hypertension in men. J Hum Hypertens 2006;20:631-634.

10 Hsu CY, McCulloch CE, Darbinian J, Go AS, Iribarren C: Elevated blood pressure and risk of end-stage renal disease in subjects without baseline kidney disease. Arch Intern Med 2005; 165:923-928.

11 Diamond JR: Analogous pathobiologic mechanisms in glomerulosclerosis and atherosclerosis. Kidney Int Suppl 1991;31:S29S34.

12 Keane WF, Kasiske BL, O’Donnell MP: Lipids and progressive glomerulosclerosis. A model analogous to atherosclerosis. Am J Nephrol 1988;8:261-271.

13 Remuzzi G, Bertani T: Pathophysiology of progressive nephropathies. N Engl J Med 1998;339:1448-1456. 
14 Chen YF, Li PL, Zou AP: Effect of hyperhomocysteinemia on plasma or tissue adenosine levels and renal function. Circulation 2002;106:1275-1281.

15 Ingram AJ, Krepinsky JC, James L, Austin RC, Tang D, Salapatek AM, Thai K, Scholey JW: Activation of mesangial cell MAPK in response to homocysteine. Kidney Int 2004; 66:733-745.

16 Shastry S, Ingram AJ, Scholey JW, James LR: Homocysteine induces mesangial cell apoptosis via activation of p38-mitogen-activated protein kinase. Kidney Int 2007;71:304-311.

17 Li N, Chen L, Muh RW, Li PL: Hyperhomocysteinemia associated with decreased renal transsulfuration activity in Dahl S rats. $\mathrm{Hy}-$ pertension 2006;47:1094-1100.

18 Ninomiya T, Kiyohara Y, Kubo M, Tanizaki Y, Tanaka K, Okubo K, Nakamura H, Hata J, Oishi Y, Kato I, Hirakata H, Iida M: Hyperhomocysteinemia and the development of chronic kidney disease in a general population: the Hisayama study. Am J Kidney Dis 2004;44:437-445.
19 Samuelsson O, Lee DM, Attman PO, KnightGibson C, Mullen JK, Larsson R, Mulec H, Weiss L, Alaupovic P: The plasma levels of homocysteine are elevated in moderate renal insufficiency but do not predict the rate of progression. Nephron 1999;82:306-311.

20 Sarnak MJ, Wang SR, Beck GJ, Kusek JW, Selhub J, Greene T, Levey AS: Homocysteine, cysteine, and B vitamins as predictors of kidney disease progression. Am J Kidney Dis 2002;40:932-939.

21 Chia EM, Wang JJ, Rochtchina E, Smith W, Cumming RR, Mitchell P: Impact of bilateral visual impairment on health-related quality of life: the Blue Mountains Eye Study. Invest Ophthalmol Vis Sci 2004;45:71-76.

22 Nexo E, Engbaek F, Ueland PM, Westby C, O'Gorman P, Johnston C, Kase BF, Guttormsen AB, Alfheim I, McPartlin J, Smith D, Moller J, Rasmussen K, Clarke R, Scott JM, Refsum H: Evaluation of novel assays in clinical chemistry: quantification of plasma total homocysteine. Clin Chem 2000;46:11501156.

23 Shankar A, Wang JJ, Rochtchina E, Mitchell P: Positive association between plasma fibrinogen level and incident hypertension among men: population-based cohort study. Hypertension 2006;48:1043-1049.
24 Chobanian AV, Bakris GL, Black HR, Cushman WC, Green LA, Izzo JL Jr, Jones DW, Materson BJ, Oparil S, Wright JT Jr, Roccella EJ, the National High Blood Pressure Education Program Coordinating Committee: Seventh Report of the Joint National Committee on Prevention, Detection, Evaluation, and Treatment of High Blood Pressure. Hypertension 2003;42:1206-1252.

25 Levey AS, Bosch JP, Lewis JB, Greene T, Rogers N, Roth D: A more accurate method to estimate glomerular filtration rate from serum creatinine: a new prediction equation. Modification of Diet in Renal Disease Study Group. Ann Intern Med 1999;130:461-470.

26 Friedman AN, Bostom AG, Selhub J, Levey AS, Rosenberg IH: The kidney and homocysteine metabolism. J Am Soc Nephrol 2001;12:2181-2189.

27 Vanholder R, Massy Z, Argiles A, Spasovski G, Verbeke F, Lameire N: Chronic kidney disease as cause of cardiovascular morbidity and mortality. Nephrol Dial Transplant 2005;20:1048-1056. 
Copyright: S. Karger AG, Basel 2008. Reproduced with the permission of S. Karger AG, Basel. Further reproduction or distribution (electronic or otherwise) is prohibited without permission from the copyright holder. 